\title{
Communication/Comunicação
}

\section{Candida dubliniensis does not show phospholipase activity: true or false?}

\section{Candida dubliniensis não evidencia atividade fosfolipásica: verdadeiro ou falso?}

\author{
Liliane Alves Scheid ${ }^{1}$, Débora Alves Nunes Mario ${ }^{1}$, Paulo Guilherme Markus Lopes ${ }^{1}$, Érico de Loreto ${ }^{2}$, \\ Carlos Eduardo Blanco Linares ${ }^{3}$, Janio Morais Santurio ${ }^{4}$ S Sydney Hartz Alves ${ }^{1,4}$
}

\begin{abstract}
Introduction: The phospholipase activity in Candida albicans and Candida dubliniensis isolated from oral candidiasis cases were studied. Methods: The phospholipase activity was evaluated in egg yolk agar. Results: All the C. albicans isolates $(\mathrm{n}=48)$ showed phospholipase activity (mean $\mathrm{Pz}$ $=0.66)$. However, none of the C. dubliniensis isolates $(\mathrm{n}=24)$ showed this activity. Conclusions: The authors discuss whether these findings are a true characteristic of $C$. dubliniensis or a consequence of the methodology employed, which includes the possibility that $\mathrm{NaCl}$ may have inhibited the enzymatic activity of $C$. dubliniensis.
\end{abstract}

Key-words: Candida albicans. Candida dubliniensis. Phospholipase activity.

\section{RESUMO}

Introdução: Avaliou-se a atividade fosfolipásica em Candida albicans e Candida dubliniensis isoladas de casos de candidíase oral. Métodos: A atividade de fosfolipase foi avaliada em ágar gema de ovo. Resultados: Todos os isolados de C. albicans $\left(\mathrm{n}^{\mathrm{o}}=48\right)$ evidenciaram atividade fosfolipásica (média $\mathrm{Pz}=0.66$ ). Todavia, nenhum isolado de C. dubliniensis $(\mathrm{n}=24)$ demonstrou esta atividade. Conclusões: Os autores discutem se estes achados são uma característica verdadeira de $C$. dubliniensis ou uma conseqüência da metodologia empregada, a qual inclui a possibilidade de que o $\mathrm{NaCl}$ seja inibidor da atividade enzimática de C. dubliniensis.

Palavras-chaves: Candida albicans. Candida dubliniensis. Atividade de fosfolipase.

The virulence of yeast species is a multifactorial property dependent on many different virulence factors, including adhesion to the host cells, formation of hyphae, phenotypic switching and production of hydrolytic enzymes such as proteinases and phospholipases ${ }^{1-3}$. Candida albicans shows these putative virulence factors, but there has been less investigation of these phenotypic characteristics in Candida dubliniensis, particularly its phospholipase activity. So far, only two studies have on reported the production of

\footnotetext{
1. Pharmaceutical Sciences Post-Graduate Program, Universidade Federal de Santa Maria. Santa Maria, RS. 2. Department of Chemistry, Universidade Federal de Santa Maria. Santa Maria, RS. 3. Department of Health Sciences, Universidade Regional do Alto Uruguai Campus de Frederico Westphalen. Santa Maria, RS, 4. Department of Microbiology and Parasitology. Universidade Federal de Santa Maria. Santa Maria, RS.
}

Address to: Prof. Sydney Hartz Alves. Rua dos Andradas 1985/201. 97010-033 Santa Maria, RS, Brazil.

Telefax: $55553220-8906$

Received in 09/12/2009 Accepted in 18/01/2010 phospholipases, and only in a limited quantity of C. dubliniensis ${ }^{2,4}$. This study aimed to compare the phospholipase activity of $C$. albicans and C. dubliniensis that were isolated from clinical specimens.

We studied twenty-four clinical strains of C. dubliniensis and forty-eight strains of C. albicans, both recovered from oral candidiasis lesions in AIDS patients. The C. dubliniensis isolates were obtained from different medical centers in Brazil between 1998 and 2007. The C. albicans isolates were obtained from the University Hospital of Santa Maria (Santa Maria, Rio Grande do Sul, Brazil) between 1995 and 2005 . All the isolates were maintained at $-70^{\circ} \mathrm{C}$. The results from phenotypic identification tests on C. dubliniensis were confirmed by genotypic methods using randomly amplified polymorphic DNA (RAPD) and using the primers CDU (5' GCGATCCCC3') and B-14 (5' GATCAAGTC3') (Bauer et $\mathrm{al}^{5}$ ). C. albicans isolates were identified using classical methods. The production of phospholipases by C. albicans and C. dubliniensis was investigated by means of culture media ${ }^{6}$ and techniques described by Price et $\mathrm{al}^{7}$ and Saramanayake et $\mathrm{al}^{8}$. C. albicans CBS 2730, C. albicans 2630 and C. dubliniensis CBS 7987 were included as controls.

Phospholipase activity of C. albicans was detected in all 48 of our assayed strains, which resulted in $\mathrm{Pz}$ ranges from 0.41 to 0.80 (mean $=0.66)$. However, phospholipase activity for $C$. dubliniensis was absent. The colonies of C. albicans developed dense growth, which resulted in a cream-like opaque zone around the colonies in the medium. In contrast, C. dubliniensis colonies scarcely developed, and no opaque halo surrounding the colonies was observed. None of the C. dubliniensis strains showed phospholipase activity.

Phospholipase exoenzymes are considered to play an important role in the pathogenesis of opportunistic fungi, as well as an active role in the invasion of host tissue during candidiasis'. By cleaving phospholipids, phospholipase destabilizes the membrane and promotes cell lysis ${ }^{3}$. Since Price et $\mathrm{al}^{7}$ described a plate method for detection of phospholipase activity in C. albicans, it has become the traditional screening method for phospholipase activity among Candida species, as well as for other yeast-like fungi such as Cryptococcus neoformans ${ }^{3}$ and Malassezia pachydermatis ${ }^{6}$. In the present study, we demonstrated that $C$. dubliniensis did not have any extracellular phospholipase activity. In our opinion, this result requires new studies, because the medium indicated by Price et $\mathrm{al}^{7}$ is composed of 5.73 gram $\% \mathrm{NaCl}$, which seems to be an inhibitory factor for $C$. dubliniensis growth. We previously demonstrated that Sabouraud broth with $6.5 \% \mathrm{NaCl}$ was inhibitory for C. dubliniensis, and then proposed a simple test for C. dubliniensis screening ${ }^{1}$. 
We therefore assume that the phospholipase activity of $C$. dubliniensis cannot be assayed using Price's method ${ }^{7}$, which could explain the scarcity of studies focusing on this virulence factor in relation to the biology of $C$. dubliniensis. Results similar to ours were reported by Hannula et $\mathrm{al}^{4}$, applying the same methodology that we used; however, those authors did not emphasize this finding. More recently, Fotedar \& Al-Hedaithy ${ }^{2}$ studied 87 C. dubliniensis strains and observed that none showed phospholipase activity, even after prolonging the incubation for seven days. Under those conditions, they reported that colonies with dense growth formed but did not have any enzymatic activity in Price's medium ${ }^{7}$. The relationship between $\mathrm{NaCl}$ and scarce growth was also observed for C. albicans in a hypertonic medium containing $6.5 \% \mathrm{NaCl}$, which explains why incubation took four days in that test ${ }^{1}$. C. dubliniensis, which is more sensitive, showed no growth under these conditions. Studies focusing on virulence factors have shown that $C$. dubliniensis is less virulent than C. albicans ${ }^{2,9}$. Would the phospholipase be the main cause of this characteristic? Based on our observations, new and more rigorous studies, such as biochemical analysis using radiometric or colorimetric assays, are needed in order to answer this question. In addition, gene cloning will elucidate the presence, activity and role of extracellular phospholipase as a virulence factor relating to C. dubliniensis ${ }^{3}$.

\section{CONFLICT OF INTEREST}

The authors declare that there is no conflict of interest.

\section{REFERENCES}

1. Alves SH, Milan EP, Laet Sant'Ana P, Oliveira LTO, Santurio, Colombo AL. Hypertonic Sabouraud broth as a simple and powerful test for Candida dubliniensis screening. Diagnostic Microbiol and Infect Dis 2002; 43: 85-86.

2. Fotedar R, Al-Hedaithy SSA. Comparison of phospholipase and proteinase activity in Candida albicans and C. dubliniensis. Mycoses 2005; 48: 62-67.

3. Ghannoum MA. Potencial role of phospholipases in virulence and fungal pathogenesis. Clinical Microbiology Reviews 2000; 13: 123-143.

4. Hannula J, Saarela M, Dogan B, Paatsama J, Koukila-Kahkola P, Pirinen S, et al. Comparison of virulence factors of oral Candida dubliniensis and Candida albicans isolates in healthy people and patients with chronic candidosis. Oral Microbiol and Immunol 2000; 15: 238-244.

5. Bauer D, Muller H, Reich J, Riedel H, Ahrenkel V, Warthoe P, et al. Identification of differentially expressed mRNA tests by an improved technique (DDRT-PCR). Nucleic Acids Research 1993; 21: 4272-4280.

6. Coutinho SD, \& Paula CR. Proteinase, phospholipase, hyaluronidase and chondroitin sulphatase production by Malassezia pachydermatis. Med Mycol 2000; 38: 73-76.

7. Price MF, Wilkinson ID, \& Gentry LO. Plate method for detection of phospholipase acrivity in Candida albicans. Sabouraudia 1982; 20: 7-14, 1982.

8. Samaranayake LP, Raeside JM, Mac Farlane TW. Factors affecting the phospholipase activity of Candida species in vitro. Sabouraudia 1984; 22: 201 207.

9. Sullivan DJ, Westerneng TJ, Haynes KA, Bennett DE, Coleman DC. Candida dubliniensis sp. Nov: phenotypic and molecular characterization of a novel species associated with oral candidosis in HIV-infected individuals. Microbiol 1995; 141: 1507-1521. 